\title{
Growth of seedlings and young plants of coffee in composts of textile industry residues
}

\author{
Eudes Neiva Júnior ${ }^{1}$, André C. França ${ }^{1}$, Paulo H. Grazziotti ${ }^{1}$, \\ Douglas W. B. Porto ${ }^{1}$, Fausto H. V. Araújo ${ }^{1} \&$ Felipe D. S. Leal $^{2}$ \\ ${ }^{1}$ Universidade Federal dos Vales do Jequitinhonha e Mucuri/Campus JK/Departamento de Agronomia. Diamantina, MG, Brasil. E-mail: eudesneiva@hotmail.com \\ (Corresponding author) - ORCID: 0000-0002-2826-867X; cabralfranca@yahoo.com.br - ORCID: 0000-0002-9009-3903; graziot@yahoo.com.br - ORCID: 0000- \\ 0002-9252-3065; douglasw1996@hotmail.com - ORCID: 0000-0002-9754-544X; faustonura@gmail.com - ORCID: 0000-0002-4210-986X \\ ${ }^{2}$ Universidade Federal de Lavras/Departamento de Fitopatologia. Lavras, MG, Brasil. E-mail: felipelealagro@hotmail.com - ORCID: 0000-0002-4327-9270
}

\begin{abstract}
The final destination of solid industrial waste is one of the main environmental problems currently facing, due to its potential for contamination. With the evolution of environmental policy and awareness, the proper destination of these wastes is stimulated, seeking new technologies to fulfil the demand for the products generated. One of the solutions to this environmental problem is to use these residues as fertilizers in agriculture. The objective of this study was to evaluate the use of toxic textile residues as a substrate component of coffee seedlings and as fertilizer in the initial growth of coffee plants. The study was divided into three experiments: production of seedlings, initial growth of potted plants and in the field. In the production of seedlings, the treatments consisted of different proportions of organic compost residues from the textile industry: $0,4,8,16$ and $32 \%$ and a conventional treatment of seedling production. In pots and in the field, the same treatments were used with organic compound, and a conventional planting treatment. In the three experiments, plant growth and nutritional analyses were performed. The conventional treatment provided better development of the seedlings and the potted and field coffee plants for most of the evaluated parameters. The treatments between 8 and 16\% of organic compost showed an acceptable development of coffee plants, demonstrating their potential as fertilizer.
\end{abstract}

Key words: organic fertilization, Coffea arabica, composting

\section{Crescimento de mudas e plantas jovens de cafeeiro em composto de resíduos da indústria têxtil}

\begin{abstract}
RESUMO: A destinação final de resíduos sólidos industriais é um dos principais problemas ambientais enfrentados atualmente devido ao seu potencial de contaminação. Com a evolução da política e consciência ambiental, a destinação adequada desses resíduos é estimulada, buscando-se novas tecnologias para suprir a demanda dos produtos gerados. Uma das soluções para esse problema ambiental é a utilização desses resíduos como fertilizantes na agricultura. Objetivou-se com esse trabalho avaliar o uso de composto de resíduos tóxicos da indústria têxtil como componente de substrato de produção de mudas de café e como fertilizante no crescimento inicial de plantas de café. $\mathrm{O}$ estudo foi dividido em três experimentos: produção de mudas, crescimento inicial das plantas em vasos e no campo. Na produção de mudas, os tratamentos constaram de diferentes proporções de composto orgânico de resíduo da indústria têxtil: $0,4,8,16$ e 32\% e um tratamento convencional de produção de mudas. Em vasos e no campo foram utilizados os mesmos tratamentos com composto orgânico e um tratamento convencional de plantio. Nos três experimentos foram realizadas análises de crescimento e nutricional das plantas. $\mathrm{O}$ tratamento convencional proporcionou melhor desenvolvimento das mudas e das plantas de café em vasos e em campo, para a maioria dos parâmetros avaliados. Os tratamentos entre 8 e $16 \%$ de composto orgânico apresentaram desenvolvimento aceitável das plantas de cafeeiro, demonstrando o seu potencial como fertilizante.
\end{abstract}

Palavras-chave: adubação orgânica, Coffea arabica, compostagem 


\section{INTRODUCTION}

Adequate disposing of solid wastes generated in industries has become one of the major environmental problems faced nowadays, due to their potential of contamination. Cotton thread waste containing oil and grease, used in machine maintenance, are classified as highly toxic wastes (Class I) and must be treated before exposure to any environment (Brasil, 2010).

Addition of cotton thread waste containing oil and grease in composting using bovine manure results in a compost with characteristics equivalent to those of the substrate conventionally used to produce eucalyptus seedlings. In addition, composting is efficient in the treatment of toxic wastes from textile industries (Souza et al., 2015). Incorporation of urban wastes to the soil has favorable effects, such as using tannery sludge for soil fertilization and production of corn and soybean (Costa et al., 2001; Araújo, 2011), and using sewage sludge for the production of sunflower, wheat, bean and corn (Barbosa et al., 2007; Lobo et al., 2012, 2014).

The coffee crop is highly demanding in terms of nutrients, but there are few studies evaluating products from industrial wastes, in the production of seedlings, planting of orchards and production of grains. Alternatives for soil fertilization, due to the high costs related to mineral fertilization, should be evaluated. Conilon coffee seedlings fertilized with 10 , 20,30 and $40 \%$ of tannery sludge in the substrate showed acceptable development for planting, compared to those under conventional fertilization (Berilli et al., 2014).

Thus, due to the need to find a more sustainable destination for grease and oil residues contained in cotton thread waste, this study aimed to evaluate the use of compost containing toxic wastes from textile industry as a component of substrate for the production of coffee seedlings and as fertilizer in the initial growth of coffee plants.

\section{Material and Methods}

The study was conducted in independent experiments under the following conditions: production of seedlings, initial growth of plants in pots and in the field. For all, the coffee cultivar used was Catuai Vermelho IAC 99.

The organic compost was produced from the composting of $2.31 \mathrm{~m}^{3}$ of dirty cotton cloths containing oil and grease and $0.78 \mathrm{~m}^{3}$ of bovine manure. Cotton cloths were provided by the textile industries of Diamantina and Gouveia, MG, Brazil.

After the composting pile was constructed with a cone shape, it was turned three times per week, until 90 days, and twice a week until the end of the process (176 days), when pile temperature was lower than $40{ }^{\circ} \mathrm{C}$. The compost was passed through a $15-\mathrm{mm}$-mesh sieve and had density of $0.63 \mathrm{mg} \mathrm{dm}^{-3}$ and moisture of $25 \%$. The compost was contaminated by any of the 16 aromatic polycyclic hydrocarbons considered as pollutant by the United States Environmental Protection Agency (USEPA, 1994). The compost had the following chemical characteristics: $\mathrm{pH}\left(\mathrm{H}_{2} \mathrm{O}\right)=7.0$ (soil: water ratio of $1: 2.5$ ); $\mathrm{P}=512.6 \mathrm{mg} \mathrm{dm}^{-3}$ and $\mathrm{K}=2059.0 \mathrm{mg} \mathrm{dm}^{-3}$ (Mehlich-1); $\mathrm{Ca}^{2+}=9.0 \mathrm{cmol}_{\mathrm{c}} \mathrm{dm}^{-3}, \mathrm{Mg}^{2+}=$ $3.5 \mathrm{cmol} \mathrm{dm}^{-3}$ and $\mathrm{Al}^{3+}=0.1 \mathrm{cmol} \mathrm{dm}^{-3}\left(1 \mathrm{~mol} \mathrm{~L}^{-1} \mathrm{KCl}\right) ; \mathrm{H}+\mathrm{Al}$ $=1.1 \mathrm{cmol} \mathrm{dm}^{-3}\left(0.5 \mathrm{~mol} \mathrm{~L}^{-1}\right.$ calcium acetate at $\left.\mathrm{pH} 7.0\right) ; \mathrm{OM}=$
$4.9 \mathrm{dag} \mathrm{kg}{ }^{-1}$ (Walkley \& Black); $\mathrm{t}=17.8 \mathrm{cmol}_{\mathrm{c}} \mathrm{dm}^{-3} ; \mathrm{T}=18.8$ $\mathrm{cmol}_{\mathrm{c}} \mathrm{dm}^{-3} ; \mathrm{m}=1.0 \% ; \mathrm{V}=94.0 \% ; \mathrm{Zn}=364.3 \mathrm{mg} \mathrm{kg}^{-1}, \mathrm{Fe}=2.4$ $\mathrm{mg} \mathrm{kg}^{-1}, \mathrm{Cu}=175.8 \mathrm{mg} \mathrm{kg}^{-1}$ and $\mathrm{Mn}=36.8 \mathrm{mg} \mathrm{kg}^{-1}$ (Mehlich-1); $\mathrm{Cd}=0 \mathrm{mg} \mathrm{kg}{ }^{-1}, \mathrm{Ba}=0 \mathrm{mg} \mathrm{kg}^{-1}, \mathrm{~Pb}=0.1 \mathrm{mg} \mathrm{kg}^{-1}, \mathrm{Cr}=0.4 \mathrm{mg} \mathrm{kg}^{-1}$ and $\mathrm{Ni}=3.4 \mathrm{mg} \mathrm{kg}^{-1}$ (EMBRAPA, 1999).

\section{Production of seedlings}

The experiment was conducted at the Coffee Cultivation Sector of the Federal University of Jequitinhonha and Mucuri Valleys, Diamantina, MG, Brazil (18 $12^{\prime} 12^{\prime \prime}$ S, 43 34' 16" W, altitude of $1403 \mathrm{~m}$ ). The experimental design was randomized blocks with four replicates. Three coffee seeds were placed to germinate in polyethylene bags $(11 \times 22 \mathrm{~cm})$, containing soil mixed with the organic compost at proportions (v:v) of: $0,4,8$, 16 and $32 \%$ and in soil mixed with bovine manure at proportion of $30 \%$ and fertilized with $0.9 \mathrm{~kg} \mathrm{~m}^{-3}$ of $\mathrm{P}_{2} \mathrm{O}_{5}$ and $0.29 \mathrm{~kg} \mathrm{~m}^{-3}$ of $\mathrm{K}_{2} \mathrm{O}$ (conventional fertilization). Soil chemical analysis showed the following characteristics: $\mathrm{pH}\left(\mathrm{H}_{2} \mathrm{O}\right)=6.1$ (soil: water ratio of 1:2.5); $\mathrm{P}=0.7 \mathrm{mg} \mathrm{dm}^{-3}$ and $\mathrm{K}=25 \mathrm{mg} \mathrm{dm}^{-3}$ (Mehlich-1); $\mathrm{Ca}^{2+}=$ $1.7 \mathrm{cmol}_{\mathrm{c}} \mathrm{dm}^{-3}, \mathrm{Mg}^{2+}=0.5 \mathrm{cmol} \mathrm{dm}_{\mathrm{c}} \mathrm{dm}^{-3}$ and $\mathrm{Al}^{3+}=0 \mathrm{cmol}_{\mathrm{c}} \mathrm{dm}^{-3}$ $(1 \mathrm{~mol} \mathrm{~L}-1 \mathrm{KCl}) ; \mathrm{H}+\mathrm{Al}=3.6 \mathrm{cmol} \mathrm{dm}^{-3}\left(0.5 \mathrm{~mol} \mathrm{~L}^{-1}\right.$ calcium acetate at $\mathrm{pH} 7.0) ; \mathrm{OM}=1.1 \mathrm{dag} \mathrm{kg}^{-1}$ (Walkley \& Black); $\mathrm{t}=$ $2.3 \mathrm{cmol}_{c} \mathrm{dm}^{-3} ; \mathrm{T}=6.0 \mathrm{cmol}_{\mathrm{c}} \mathrm{dm}^{-3} ; \mathrm{V}=38 \%$.

The bags with seeds were taken to a greenhouse and thinning was carried out when the seedlings reached the "match" stage, leaving only one seedling per bag.

After the period of 150 days, the plants were evaluated for leaf area (Antunes et al., 2008), plant height and then they were cut to evaluate shoot dry matter (SDM), leaf dry matter (LDM) and root dry matter (RDM). Then, the ratio between shoot dry matter and root dry matter (SDM/RDM) was calculated. After determining leaf dry matter, the leaves were ground in a Wiley-type mill, homogenized and sampled to determine the contents of macro- and micronutrients of the plants (Malavolta et al., 1997).

\section{Coffee growth in pots}

The experiment was conducted at the same site of the previous experiment. The experimental design was randomized blocks with four replicates. Coffee seedlings were produced by the direct seeding method in bags containing the soil described in the previous experiment mixed with bovine manure at proportion of $30 \%$ and fertilized with $0.9 \mathrm{~kg} \mathrm{~m}^{-3}$ of $\mathrm{P}_{2} \mathrm{O}_{5}$ and $0.29 \mathrm{~kg} \mathrm{~m}^{-3}$ of $\mathrm{K}_{2} \mathrm{O}$. At 150 days, the seedlings with four and five pair of leaves were transplanted to $20 \mathrm{dm}^{3}$ pots containing a mixture of the same soil and the compost at the following proportions (v:v): 0, 4, 8, 16 and $32 \%$.

The additional treatment consisted of fertilization equivalent to $0.080 \mathrm{~kg}$ per hole of $\mathrm{P}_{2} \mathrm{O}_{5}$ and $5 \mathrm{~kg}$ per hole of aged bovine manure (conventional fertilization, according to Guimarães et al., 1999), considering the volume of the pot.

Plants were kept in greenhouse for 150 days, when they were evaluated as described for the previous experiment.

\section{Coffee growth in the field}

The experiment was conducted in a field situated at the Forquilha Farm (18 31' $31^{\prime \prime} \mathrm{S}$ and $\left.43^{\circ} 51^{\prime} 19^{\prime \prime} \mathrm{W}\right)$, district of Batatal, MG, Brazil. 
Before installing the experiment, the soil had the following chemical characteristics: $\mathrm{pH}\left(\mathrm{H}_{2} \mathrm{O}\right)=6.1$ (soil:water ratio of 1:2.5); $\mathrm{P}=512.6 \mathrm{mg} \mathrm{dm}^{-3}$ and $\mathrm{K}=2059.0 \mathrm{mg} \mathrm{dm}^{-3}$ (Mehlich-1); $\mathrm{Ca}^{2+}=9.0 \mathrm{cmol}_{\mathrm{c}} \mathrm{dm}^{-3}, \mathrm{Mg}^{2+}=3.5 \mathrm{cmol}_{\mathrm{c}} \mathrm{dm}^{-3}$ and $\mathrm{Al}^{3+}=0.1$ $\mathrm{cmol}_{\mathrm{c}} \mathrm{dm}^{-3}\left(1 \mathrm{~mol} \mathrm{~L} \mathrm{~L}^{-1} \mathrm{KCl}\right) ; \mathrm{H}+\mathrm{Al}=1.1 \mathrm{cmol}_{\mathrm{c}} \mathrm{dm}^{-3}\left(0.5 \mathrm{~mol} \mathrm{~L}^{-1}\right.$ calcium acetate at $\mathrm{pH} 7.0) ; \mathrm{OM}=1.9 \mathrm{dag} \mathrm{kg}^{-1}$ (Walkley \& Black); $\mathrm{SB}=0.3 \mathrm{cmol} \mathrm{dm}^{-3} ; \mathrm{t}=0.6 \mathrm{cmol} \mathrm{dm}^{-3} ; \mathrm{T}=4.9 \mathrm{cmol} \mathrm{dm}^{-3} ; \mathrm{m}=50 \%$; $\mathrm{V}=6 \% ; \mathrm{Zn}=0.2 \mathrm{mg} \mathrm{kg}{ }^{-1}, \mathrm{Fe}=30.5 \mathrm{mg} \mathrm{kg}^{-1}, \mathrm{Mn}=0.7 \mathrm{mg} \mathrm{kg}^{-1}$ and $\mathrm{Cu}=0.1 \mathrm{mg} \mathrm{kg}^{-1}$ (Mehlich-1); $\mathrm{B}=0.1 \mathrm{mg} \mathrm{kg}^{-1}$ (hot water).

The experimental design used was randomized blocks with four replicates. 150-day-old coffee seedlings produced as described for the previous experiment were selected to standardize the size and transplanted to the field. Transplanting was performed to $40 \times 40 \times 40 \mathrm{~cm}$ holes, fertilized with the same treatments of the previous experiment, considering the volume of the hole.

At 150 days after transplanting, the number of plagiotropic branches and plant height were evaluated. Besides this, the content of $\mathrm{P}, \mathrm{K}, \mathrm{Ca}, \mathrm{Mg}, \mathrm{Cu}$ and $\mathrm{Zn}$ in leaf were determined according to methodology recommended by Malavolta et al. (1997).

\section{Data analysis}

The data of the three experiments were subjected to analysis of variance using the $\mathrm{F}$ test $(\mathrm{p} \leq 0.05)$. When significant, the means among compost proportions were assessed by regression analysis and the models were selected based on their significance, biological phenomenon and on the coefficient of determination. In the analysis of variance ( $F$ test $\mathrm{p} \leq 0.05$ ), the additional treatments were considered as sources of variation with the other treatments, for each experiment.

\section{Results AND Discussion}

\section{Production of seedlings}

Plant height, leaf area, leaf dry matter, root dry matter and SDM/RDM ratio were influenced by the addition of the organic compost (Figure 1). Highest values were observed at the following compost proportions (maximum value/compost proportion): plant height $=20.70 \mathrm{~cm} / 15.3 \%$ (Figure $1 \mathrm{~A}$ ); leaf area $=1500 \mathrm{~cm}^{2} / 14 \%$ (Figure 1B); leaf dry matter $=14.3 \mathrm{~g} / 10.9 \%$ (Figure 1C); RDM = 13 g/12.1\% (Figure 1D) and SDM/RDM $=1.6 / 16.4 \%$ (Figure 1E).

Plant height is one of the main characteristics observed by producers of coffee seedlings for their marketing. Seedlings cultivated in substrate containing the organic compost, despite being shorter than those grown in substrate containing conventional fertilization, showed height of $20.7 \mathrm{~cm}$, an acceptable value for market.

Plants cultivated in substrate containing the compost had the lower values of height, leaf area, leaf dry matter and SDM/ RDM ratio, compared to those grown in substrate containing conventional fertilization. Thus, considering the contents of nutrients after the chemical analysis of the compost, high values were observed (Malavolta, 2006) for $\mathrm{K}$ and $\mathrm{Zn}$. High values of K cause nutritional imbalance and may hamper the absorption
A.

A. 25

B
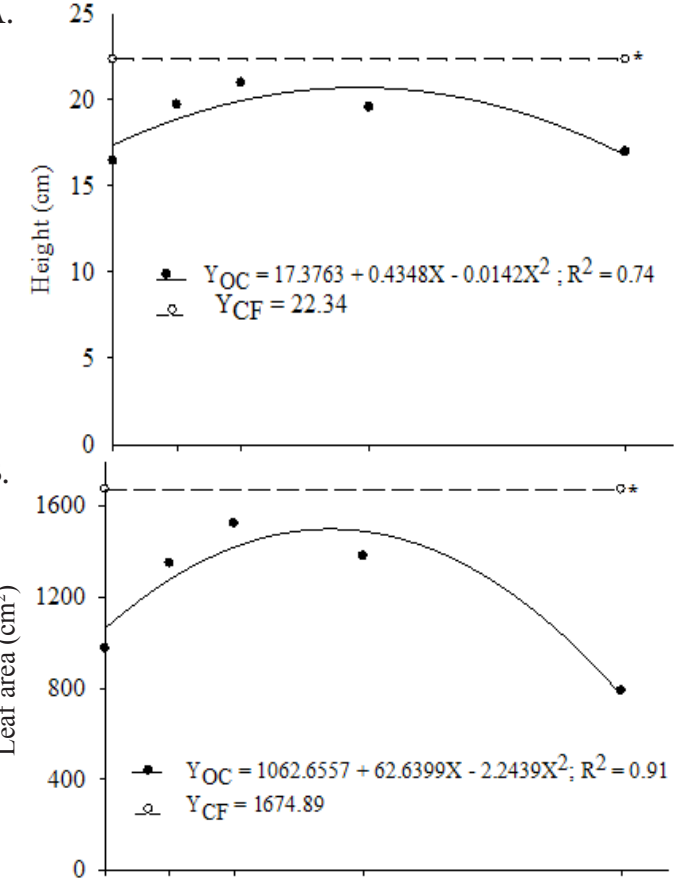

C.

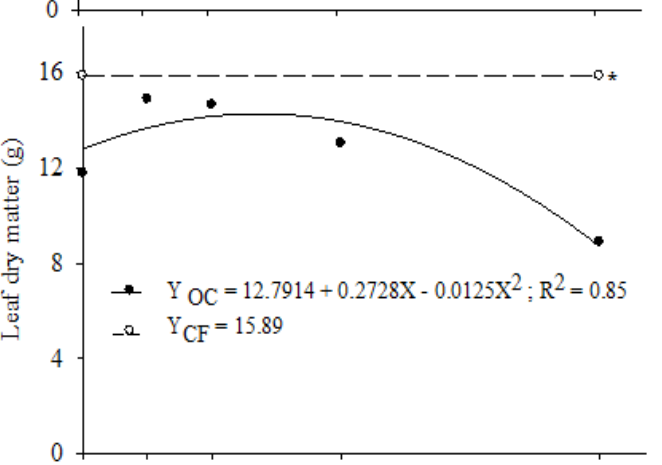

D.

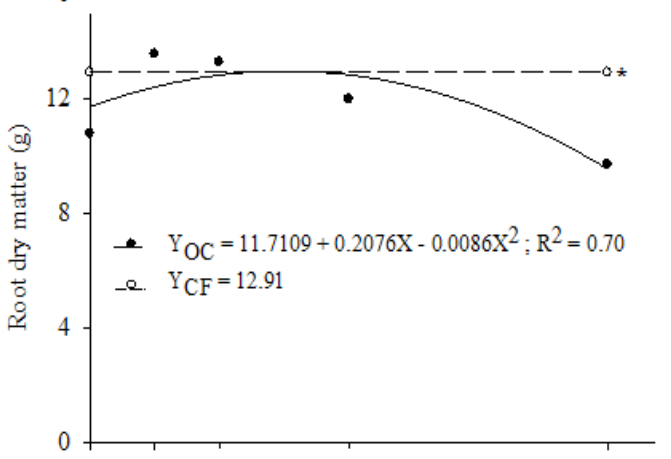

E.

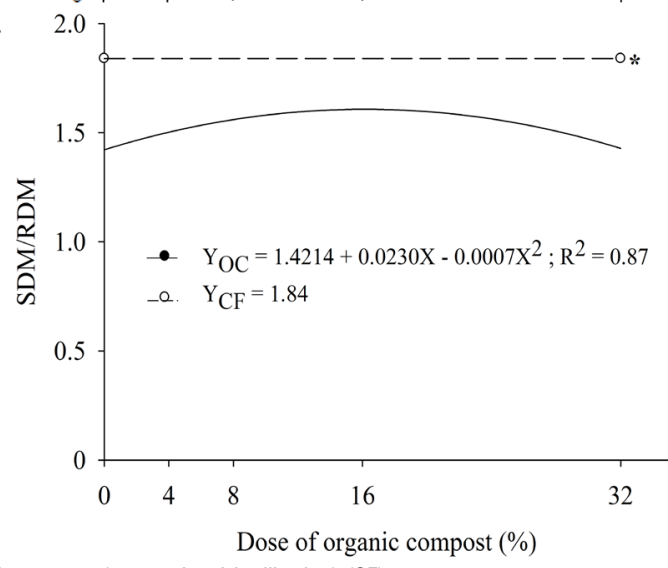

* Additional treatment (conventional fertilization) (CF)

Figure 1. Height (A), leaf area (B), leaf dry matter (C), root dry matter (D) and SDM/RDM (E) of Coffea arabica seedlings (Catuai Vermelho IAC 99) cultivated in soil fertilized with different proportions of organic compost $(\mathrm{OC})$ 
of Ca and $\mathrm{Mg}$ (Franchini et al., 1999), which leads to deleterious effect on growth and biomass accumulation by plants.

At the proportion of $12 \%$, the treatment with compost showed higher root dry matter (Figure 1D), which may be related to the high content of organic matter present in the organic compost (Berilli et al., 2014).

Highest contents of $\mathrm{P}, \mathrm{K}$ and $\mathrm{Zn}$ were observed at the following compost proportions (maximum value/compost proportion): $\mathrm{P}=1.2 \mathrm{~g} \mathrm{~kg}^{-1} / 13.6 \%$ (Figure $2 \mathrm{~A}$ ); $\mathrm{K}=21 \mathrm{~g} \mathrm{~kg}^{-1} / 16.2 \%$ (Figure $2 \mathrm{~B}$ ) and $\mathrm{Zn}=11.3 \mathrm{mg} \mathrm{kg}^{-1} / 11.2 \%$ (Figure 2C).

Critical ranges of leaf contents of $\mathrm{P}, \mathrm{K}$ and $\mathrm{Zn}$ in Arabica coffee seedlings are, respectively, equivalent to: 2.2 to $2.5 \mathrm{~g} \mathrm{~kg}^{-1}$; 25.9 to $29.2 \mathrm{~g} \mathrm{~kg}^{-1}$ and 3.7 to $4.1 \mathrm{mg} \mathrm{kg}^{-1}$ (Gontijo et al., 2007; Gonçalves et al., 2009). Thus, the treatments did not lead to plants with ideal contents of $\mathrm{P}$ and, despite the high concentration of this macronutrient in the substrate, probably the imbalance caused by the other nutrients caused lower contents of this element in the leaves (Franchini et al., 1999), particularly at organic compost proportions above $13.6 \%$,
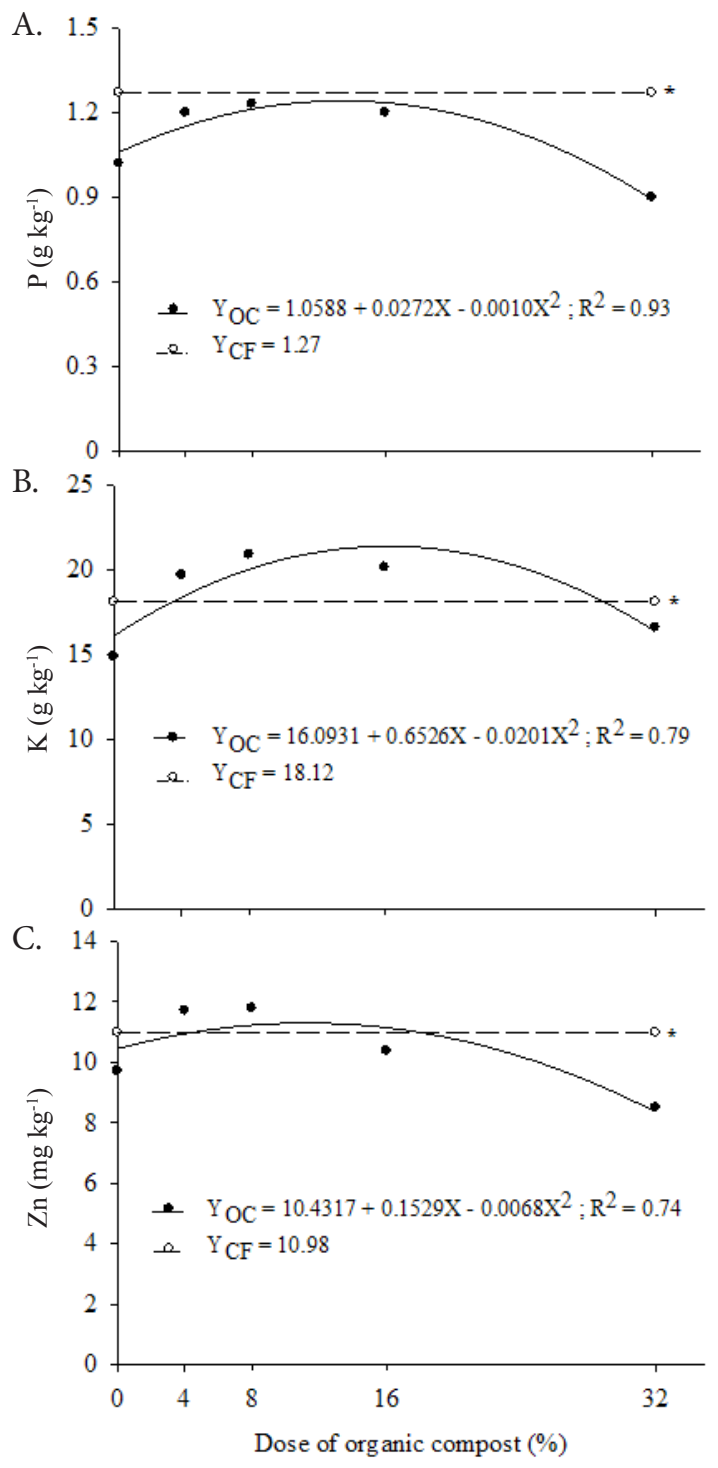

* Additional treatment (conventional fertilization) (CF)

Figure 2. Phosphorus contents $(P)(A)$, potassium $(K)(B)$ and zinc (Zn) (C) of Coffea arabica seedlings (Catuai Vermelho IAC 99) cultivated in soil fertilized with different proportions of organic compost $(\mathrm{OC})$ where the reduction in $\mathrm{P}$ contents was equal to $6 \%$ compared to the conventional treatment. The contents of $\mathrm{K}$ were not within the critical range either, even with the high concentration of this nutrient in the substrate, because it was in the organic form, which compromises its absorption by the plant.

\section{Post-transplanting growth in pots}

The highest values were observed at the following compost proportions (maximum value/compost proportion): plant height $=46.3 \mathrm{~cm} / 8.1 \%$ (Figure $3 \mathrm{~A})$; leaf area $=2931.9 \mathrm{~cm}^{2} / 5.2 \%$ (Figure 3B); root density $=0.7 \mathrm{~g} \mathrm{~cm}^{-2} / 11.3 \%$ (Figure 3C); leaf dry matter $=32.9 \mathrm{~g} / 4.1 \%$ (Figure $3 \mathrm{D})$; root dry matter $=27 \mathrm{~g} / 11.5 \%$ (Figure 3E).

From the addition of $8 \%$ of organic compost in the substrate, there was a reduction in plant height, leaf area and leaf dry matter (Figures $3 \mathrm{~A}, \mathrm{~B}$ and $\mathrm{E}$ ), due to the high concentrations of $\mathrm{K}\left(19.8 \mathrm{~g} \mathrm{~kg}^{-1}\right), \mathrm{Zn}\left(13.7 \mathrm{mg} \mathrm{kg}^{-1}\right)$ and $\mathrm{Cu}$ $\left(18 \mathrm{mg} \mathrm{kg}^{-1}\right)$ (Figure 4), which cause nutritional imbalance with $\mathrm{P}, \mathrm{Ca}$ and $\mathrm{Mg}$, leading to lower development of plant shoots.

Plants grown in soil with organic compost showed higher values of root density and root dry matter compared to those under conventional fertilization, at proportions of approximately 4 to $22 \%$. Similar results were observed by Andrade Neto et al. (1999) in coffee plants cultivated in substrates composed of cattle manure, poultry manure or residue from coffee processing machine, in comparison to conventional fertilization.

Higher values of biomass accumulation by roots were not related to the greater development of the shoots. Probably, it could be explained by the leaf contents of nutrients below the critical level, osmotic stress, or even the nutritional imbalance, which stimulate greater root growth in a strategy of the plant to occupy larger soil volume, but with no positive effect on the shoots (Berilli et al., 2014).

Highest concentrations of $\mathrm{P}, \mathrm{K}, \mathrm{Cu}$ and $\mathrm{Zn}$ were observed at the following compost proportions (maximum value/compost proportion): $\mathrm{P}=1.26 \mathrm{~g} \mathrm{~kg}^{-1} / 0.5 \%$ (Figure $4 \mathrm{~A}$ ); $\mathrm{K}=19.8 \mathrm{~g} \mathrm{~kg}^{-1}$ $/ 13.2 \%$ (Figure $4 \mathrm{~B}$ ) $\mathrm{Cu}=18 \mathrm{mg} \mathrm{kg}^{-1} / 17.1 \%$ (Figure $4 \mathrm{C}$ ) and $\mathrm{Zn}$ $=13.7 \mathrm{mg} \mathrm{kg}^{-1} / 13.1 \%$ (Figure $4 \mathrm{D}$ ).

From the addition of the lowest proportion of the organic compost, there were reductions in P contents (Figure 4A). This is probably due to the unavailability of $\mathrm{P}$ due to the effect of high $\mathrm{Zn}$ content or high $\mathrm{pH}$ value, influenced by the organic compost (Santos et al., 2007). The $\mathrm{pH}$ value of the compost produced was equivalent to 7.0 and, in addition, soil $\mathrm{pH}$ was 6.1 when the seedlings were transplanted. Addition of organic composts to the soil has been related to increase of $\mathrm{pH}$ due to the ligand exchange between organic anions and terminal $\mathrm{OH}^{-}$ groups of Fe and $\mathrm{Al}$ oxides (Franchini et al., 1999).

The critical range of $\mathrm{P}$ for coffee plants in the first year of production is from 1.1 to $1.2 \mathrm{~g} \mathrm{~kg}^{-1}$ (Clemente et al., 2008). Such range of concentration was attained with the application of organic compost at proportions between 0 and $20 \%$. Therefore, it can be inferred that even with reduction in the leaf contents of $\mathrm{P}$, as the organic compost proportions increased, the ideal content of $\mathrm{P}$ in coffee leaves was achieved.

The $\mathrm{K}$ contents in the leaves of plants grown in soil with addition of 6 to $21 \%$ of organic compost were higher than those of plants cultivated in soil with conventional fertilization. The 

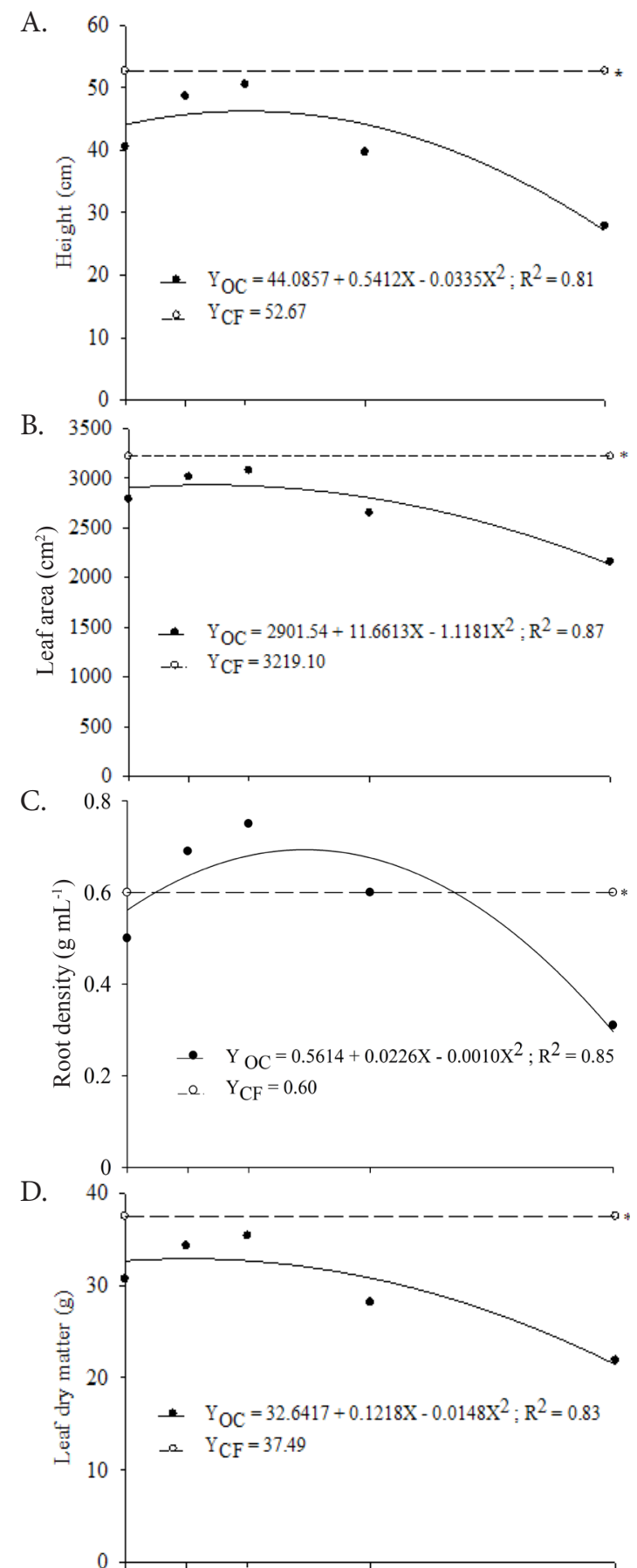

E.

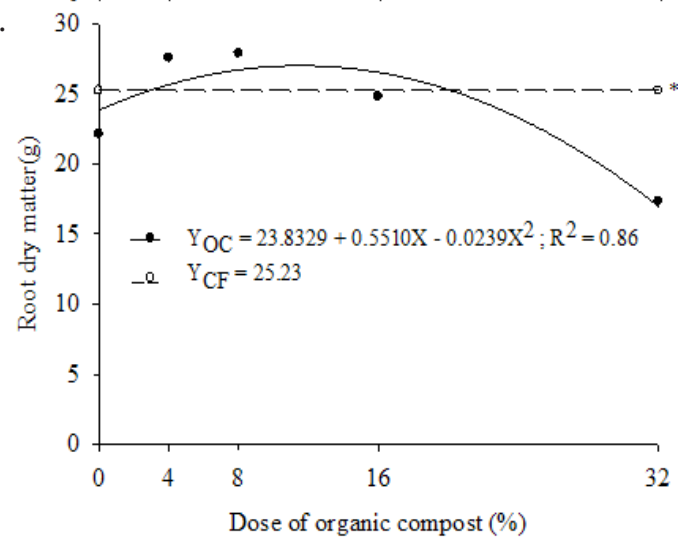

${ }^{*}$ Additional treatment (conventional fertilization) (CF)

Figure 3. Height $(A)$, leaf area $(B)$, root density $(C)$, leaf dry matter (D) and root dry matter (E) of Coffea arabica plants (Catuai Vermelho IAC 99) cultivated in soil fertilized with different proportions of organic compost $(\mathrm{OC})$
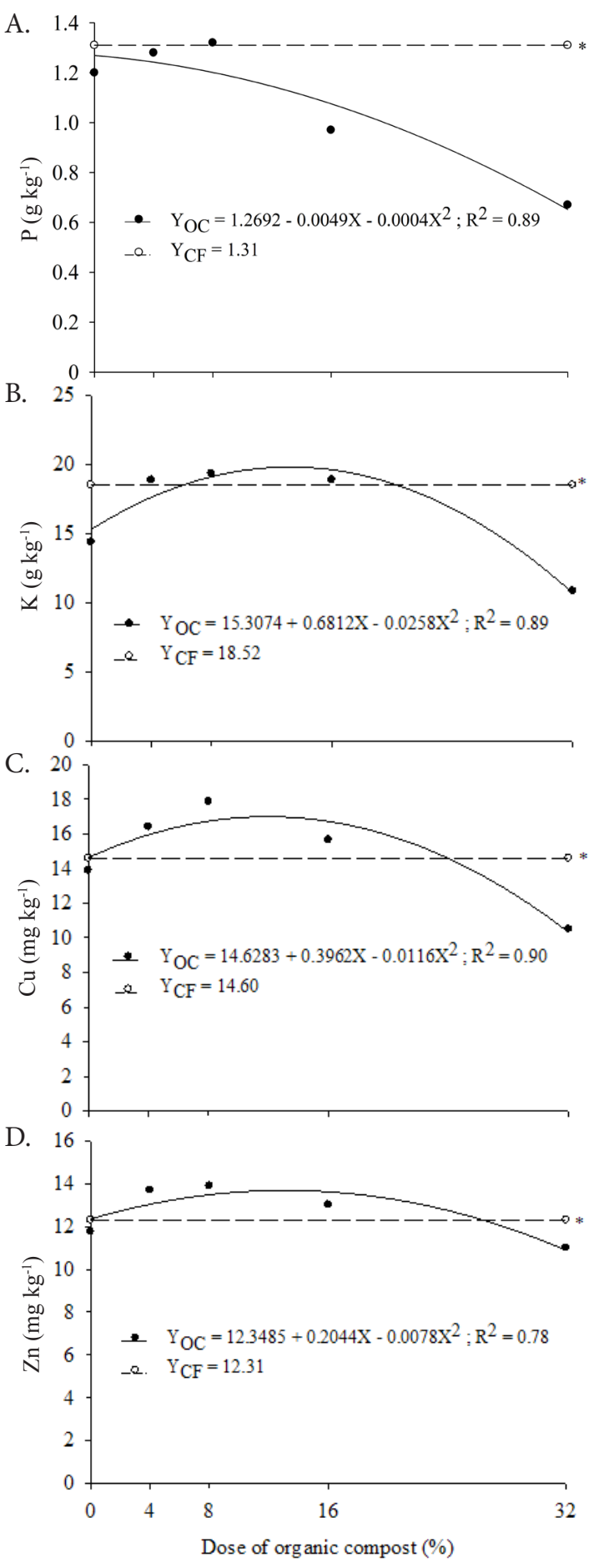

* Additional treatment (conventional fertilization) (CF)

Figure 4. Phosphorus contents $(\mathrm{P})(\mathrm{A})$, potassium $(\mathrm{K})(\mathrm{B})$, cooper $(\mathrm{Cu})(\mathrm{C})$ and zinc $(\mathrm{Zn})(\mathrm{D})$ of Coffea arabica plants (Catuai Vermelho IAC 99) cultivated in soil fertilized with different proportions of organic compost $(\mathrm{OC})$

maximum content of $\mathrm{K}$ observed was higher than that defined by Pinto et al. (2013). This content was $6.9 \%$ higher than that found under conventional fertilization $\left(18.5 \mathrm{~g} \mathrm{~kg}^{-1}\right)$, due to the greater supply of $\mathrm{K}$ in the organic compost.

For the contents of $\mathrm{Cu}$ and $\mathrm{Zn}$, higher values were observed in the leaves of plants cultivated in soil fertilized with organic compost, compared to plants under conventional fertilization. This result may be attributed to the high concentration of these nutrients available in the organic compost. 


\section{Experiment in the field}

The number of plagiotropic branches and plant height were influenced by the addition of the organic compost in the planting hole (Figure 5). The highest values were observed at the following compost proportions (maximum value/ compost proportion): number of plagiotropic branches $=7.4 / 13.7 \%$ (Figure 5A) and plant height $71.4 \mathrm{~cm} / 8.2 \%$ (Figure $5 \mathrm{~B}$ ). This proportion at which plant height was maximum was close to the maximum proportion observed for plants transplanted to pots $(8.1 \%)$, and was lower than the maximum proportion observed for the production of seedlings (15.3\%).

Lower growth of plants cultivated in soil with higher doses of organic compost possibly occurred due to the nutritional imbalance and the toxic effects caused by the high availability of $\mathrm{K}, \mathrm{Zn}$ and $\mathrm{Cu}$ (Malavolta, 2006).

The contents of nutrients also varied according to the addition of organic compost in the cultivation soil, and there was an increase with the addition of lower compost proportions (Figure 6). Highest values were found at the following compost proportions (maximum value/compost proportion): $\mathrm{P}=1.6$ $\mathrm{g} \mathrm{kg}^{-1} / 13.7 \%$ (Figure 6A); $\mathrm{K}=26.4 \mathrm{~g} \mathrm{~kg}^{-1} / 15.4 \%$ (Figure 6B); $\mathrm{Ca}=9 \mathrm{~g} \mathrm{~kg}^{-1} / 12.7 \%$ (Figure 6C); $\mathrm{Mg}=5.4 \mathrm{~g} \mathrm{~kg}^{-1} / 13.01 \%$ (Figure $6 \mathrm{D}) ; \mathrm{Cu}=12.1 \mathrm{mg} \mathrm{kg}^{-1} / 12 \%$ (Figure $6 \mathrm{E}$ ); $\mathrm{Zn}=15.8 \mathrm{mg} \mathrm{kg}^{-1} / 15.2 \%$ (Figure 6F).

The maximum $\mathrm{P}$ content in plants cultivated with organic compost was higher than that observed in plants cultivated under conventional fertilization. Despite that, this $\mathrm{P}$ content
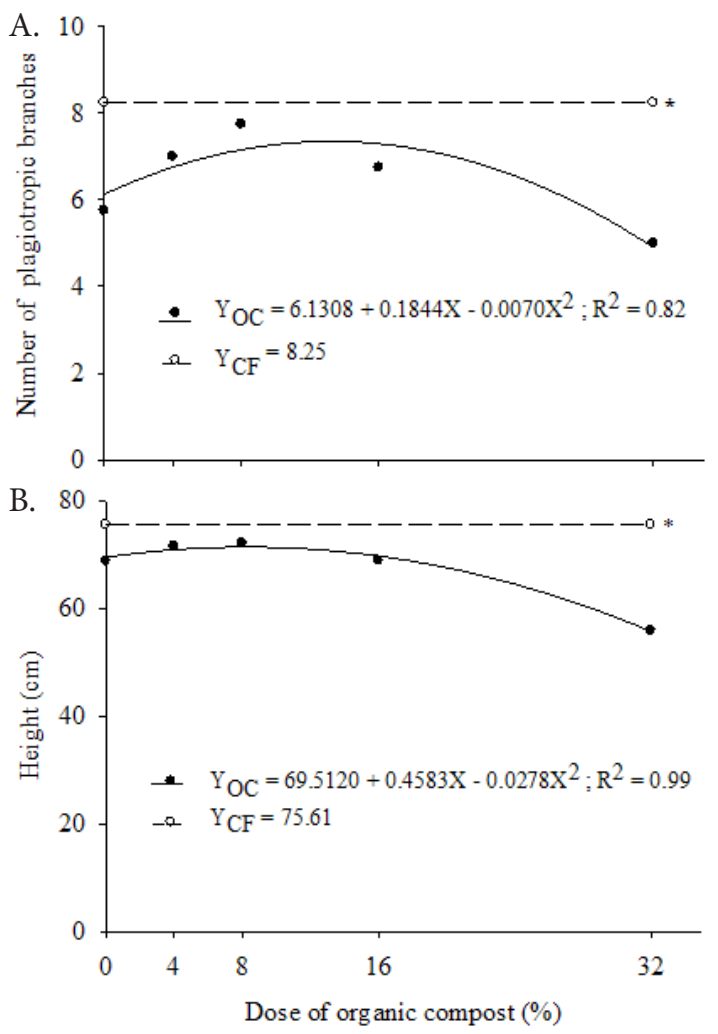

* Additional treatment (conventional fertilization) (CF)

Figure 5. Number of plagiotropic branches $(A)$ and height (B) of Coffea arabica plants (Catuai Vermelho IAC 99) cultivated in soil fertilized with different proportions of organic compost $(\mathrm{OC})$
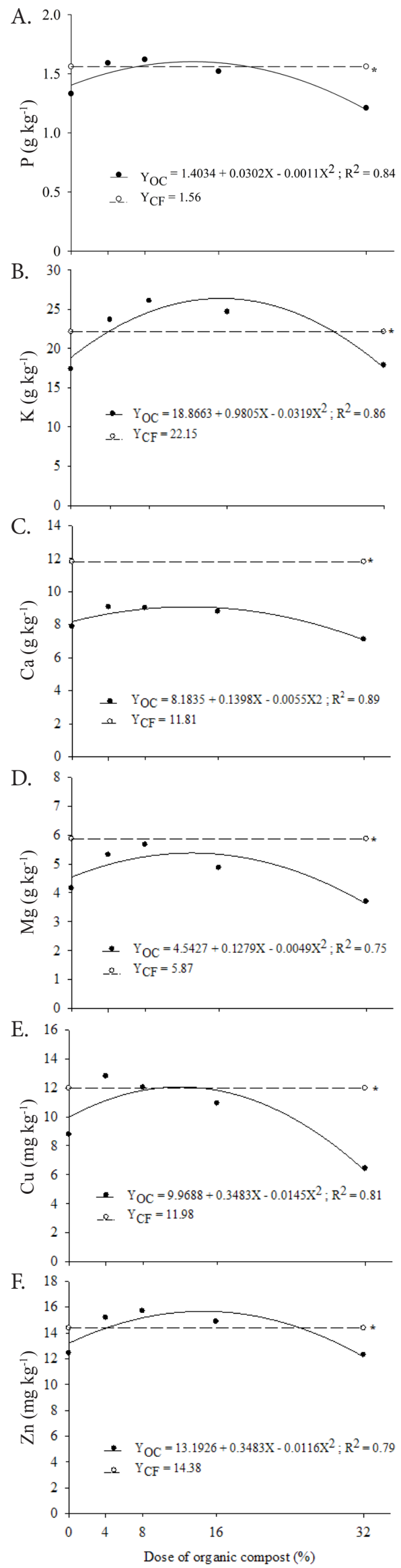

* Additional treatment (conventional fertilization) (CF)

Figure 6. Phosphorus contents $(P)(A)$, potassium $(K)(B)$, calcium $(\mathrm{Ca})(\mathrm{C})$, magnesium $(\mathrm{Mg})(\mathrm{D})$, copper $(\mathrm{Cu})(\mathrm{E})$ and zinc $(\mathrm{Zn})(\mathrm{F})$ of Coffea arabica plants (Catuai Vermelho IAC 99) cultivated in soil fertilized with different proportions of organic compost $(\mathrm{OC})$ 
is below the ideal range recommended by Clemente et al. (2008), from 17.39 to $19.02 \mathrm{~g} \mathrm{~kg}^{-1}$. The contents of $\mathrm{K}$ are above the range recommended by this author, 12.7 to $14.11 \mathrm{~g} \mathrm{~kg}^{-1}$. As already mentioned, low $\mathrm{P}$ contents in the leaves, even with high concentration in the substrate, are related to nutritional imbalance and high pH (Franchini et al., 1999) and the higher $\mathrm{K}$ contents were quantified due to the greater availability of this nutrient in the compost.

The contents of $\mathrm{Ca}$ and $\mathrm{Mg}$ in the leaves of coffee plants fertilized with different compost proportions were lower than those found in the leaves of plants under conventional fertilization. This finding can be explained by the negative interference caused by the high contents of $\mathrm{K}$ available in the compost, as reported by Franchini et al. (1999). It is worth highlighting that, regardless of the fertilization used, the leaf contents of $\mathrm{Mg}$ are below those suggested by Clemente et al. (2008), from 8.3 and $9.0 \mathrm{~g} \mathrm{~kg}^{-1}$, whereas Ca contents are within the ideal range recommended by these authors (between 8.2 to $8.9 \mathrm{~g} \mathrm{~kg}^{-1}$ ).

The highest leaf content of $\mathrm{Zn}$ in plants fertilized with organic compost were superior to those of plants under conventional treatment, due to the high supply of these nutrients in the compost.

\section{Conclusions}

1. Conventional fertilization leads to better development of coffee seedlings and plants in pots and in the field, for most parameters evaluated.

2. Treatments with 8 to $16 \%$ of organic compost led to acceptable development of coffee seedlings, demonstrating its potential as fertilizer.

\section{ACKNOWLEDGMENTS}

To the Minas Gerais Research Support Foundation (FAPEMIG) and to the National Council for Scientific and Technological Development (CNPq), for providing financial resources to carry out the present study.

\section{Literature Cited}

Andrade Neto, A. de; Mendes, A. N. G.; Guimarães, P. T. G. Avaliação de substratos alternativos e tipos de adubação para a produção de mudas de cafeeiro (Coffea arabica L.) em tubetes. Ciência e Agrotecnologia, v.23, p.270-280, 1999.

Antunes, W. C.; Pompelli, M. F.; Carretero, D. M.; Matta, F. M. da. Allometric models for non-destructive leaf area estimation in coffee (Coffea arabica and Coffea canephora). Annals of Applied Biology, v.153, p.33-40, 2008. https://doi.org/10.1111/j.17447348.2008.00235.x

Araújo, F. F. Disponibilização de fósforo, correção do solo, teores foliares e rendimento de milho após a incorporação de fosfatos e lodo de curtume natural e compostado. Acta Scientiarum. Agronomy, v.33, p.355-360, 2011. https://doi.org/10.4025/ actasciagron.v33i2.1021
Barbosa, G. M. C.; Tavares Filho, J.; Brito, O. R.; Fonseca, I. C. B. Efeito residual do lodo de esgoto na produtividade do milho safrinha. Revista Brasileira de Ciência do Solo, v.31, p.601-605, 2007. https://doi.org/10.1590/S0100-06832007000300020

Berilli, S. D. S.; Quiuqui, J. P. C.; Rembinski, J.; Salla, P. H. H.; Berilli, A. P. C. G.; Louzada, J. M. Utilização de lodo de curtume como substrato alternativo para produção de mudas de café Conilon. Coffee Science, v.9, p.472-479, 2014.

Brasil. Lei 12.305, de 2 de agosto de 2010. Institui a Política Nacional de Resíduos Sólidos; altera a Lei no 9.605, de 12 de fevereiro de 1998; e dá outras providências. Disponível em: <http://www2. mma.gov.br/port/conama/legiabre. cfm?codlegi=636>. Acesso em: Set. 2015.

Clemente, F. M. V. T.; Carvalho, J. G. de; Guimarães, R. J.; Mendes, A. N. G. Faixas críticas de teores foliares de macronutrientes no cafeeiro em pós-plantio - Primeiro Ano. Coffee Science, v.3, p.38-46, 2008.

Costa, C. N.; Castilhos, D.; Konrad, E.; Passianoto, C. Efeito da adição de lodos de curtume sobre as alterações químicas do solo, rendimento de matéria seca e absorção de nutrientes em soja. Revista Brasileira de Agrociência, v.7, p.189-191, 2001.

EMBRAPA - Empresa Brasileira de Pesquisa Agropecuária. Manual de análises químicas dos solos, plantas e fertilizantes. Rio de Janeiro: Embrapa Solos, 1999. 370p.

Franchini, J. C.; Malavolta, E.; Miyazawa, M.; Pavan, M. A. Alterações químicas em solos ácidos após a aplicação de resíduos vegetais. Revista Brasileira de Ciência do Solo, v.23, p.533-542, 1999. https://doi.org/10.1590/S0100-06831999000300006

Gonçalves, S. M.; Guimarães, R. J.; Carvalho, J. D. de; Botrel, E. P. Faixas críticas de teores foliares de macronutrientes em mudas de cafeeiro (Coffea arabica L.) produzidas em tubetes. Ciência e Agrotecnologia, v.33, p.743-752, 2009. https://doi.org/10.1590/ S1413-70542009000300012

Gontijo, R. A. N.; Carvalho, J. G. de; Guimarães, R. J.; Mendes, A. N. G.; Andrade, W. E. de. B. Faixas críticas de teores foliares de micronutrientes em mudas de cafeeiro (Coffea arabica L.). Coffee Science, v.2, p.135-141, 2007.

Guimarães, P. T. G.; Garcia, A. W. R.; Alvarez V., V. H.; Prezotti, L. C.; Viana, A. S.; Miguel, A. E.; Malavolta, E.; Corrêa, J. B.; Lopes, A. S.; Nogueira, F. D.; Monteiro, A. V. C.; Oliveira, J. A. Cafeeiro. In: Ribeiro, A. C.; Guimarães, P. T. G.; Alvarez V., V. H. (eds.). Recomendações para o uso de corretivos e fertilizantes em Minas Gerais: 5 aproximação. Viçosa: Comissão de Fertilidade do Solo do Estado de Minas Gerais, 1999. Cap.18, p.289-302.

Lobo, T. F.; Grassi Filho, H. G.; Bull, L. T. Efeito do nitrogênio e do lodo de esgoto nos fatores produtivos do feijoeiro. Revista Ceres, v.59, p.118-124, 2012. https://doi.org/10.1590/S0034737X2012000100017

Lobo, T. F.; Grassi Filho, H. G.; Kummer, A. C. B. Aplicações sucessivas de lodo de esgoto no girassol e efeito residual no trigo e triticale. Revista Brasileira de Engenharia Agrícola e Ambiental, v.8, p.881-886, 2014. https://doi.org/10.1590/1807-1929/agriambi. v18n09p881-886

Malavolta, E. Manual de nutrição mineral de plantas. São Paulo: Editora Agronômica Ceres, 2006. 638p.

Malavolta, E.; Vitti, G. C.; Oliveira, S. A. de. Avaliação do estado nutricional das plantas: Princípios e aplicações. 2.ed. Piracicaba: Potafos, 1997. 319p. 
Pinto, C. G.; Guimarães, J. R.; Villela, G. M.; Scalco, M. S. Faixas críticas de teores foliares de macronutrientes primários para cafeeiros fertirrigados no primeiro ano pós-plantio. Coffee Science, v.8, p.530-538, 2013.

Santos, M. H.; Batista, B. L.; Duarte, S. M. S.; Lemos, B. Influence of processing and roasting on the antioxidant activity of coffee (Coffea arabica). Química Nova, v.30, p.604-610, 2007. https:// doi.org/10.1590/S0100-40422007000300020
Souza, P. F. de; Grazziotti, D. C. F. S.; Grazziotti, P. H.; Fernandes, L. A.; Silva, E. de B.; Gandini, A. M. M. Growth of eucalyptus rooted cuttings in toxic organic waste compost of textile industry. Revista Brasileira de Engenharia Agrícola e Ambiental, v.19, p.829-834, 2015. https://doi.org/10.1590/1807-1929/agriambi.v19n9p829-834 USEPA - United States Environmental Protection Agency. Microwave assisted aciddigestion of sediments, sludges, soils and oilsMethod 3052 - SW - 846, 1994. Disponível em: <http:www.epa. gov/epaosver/hazwaste/test/3052.pdf>. Acesso em: Set. 2015. 